\title{
PENGARUH SUPLEMENTASI Heit-CHrose MELALUI BERBAGAI SISTEM PEMBERIAN PAKAN TERHADAP KONSUMSI DAN KECERNAAN PAKAN SAPI PERAH AWAL LAKTASI
}

\author{
Heit-CHroSe SUPPLEMENTATION THROUGH VARIOUS FEEDING SYSTEMS : EFFECT ON \\ FEED CONSUMPTION AND FEED DIGESTIBILITY IN EARLY LACTATION DAIRY COWS
}

\author{
Fery Kurniawan dan Caribu Hadi Prayitno* \\ Fakultas Peternakan, Universitas Jenderal Soedirman, Jl. Dr. Soeprano, Karangwangkal, Purwokerto, 53123
}

\section{INTISARI}

Penelitian ini bertujuan untuk mengetahui konsumsi dan kecernaan nutrien pakan pada sapi perah yang mendapatkan pakan dengan suplementasi mineral organik (Cr organik 1,5 ppm; Se organik 0,3 ppm; Zn-Lyzinat 40 ppm) dan Heit-CHrose (suplemen yang mengandung saponin, allisin dan mineral $\mathrm{Cr}$, Se, dan $\mathrm{Zn}$ ). Penelitian menggunakan 16 ekor sapi perah laktasi ketiga dengan rataan bobot badan $638 \pm 72 \mathrm{~kg}$ yang dibagi menjadi 4 perlakuan, yaitu R0 adalah pakan kontrol, R1 adalah R0 disuplementasi mineral organik, R2 adalah R1 ditambah Heit-CHrose diberikan secara konvensional, dan R3 adalah R2 yang diberikan secara total mix ration (TMR). Data diuji menggunakan analisis variansi dengan Rancangan Acak Lengkap menggunakan 4 ulangan. Apabila terdapat perbedaan maka diuji menggunakan uji beda nyata jujur (BNJ). Hasil penelitian menunjukkan bahwa suplementasi mineral organik dan Heit-CHrose pada pakan sapi perah tidak memberikan pengaruh terhadap konsumsi bahan kering (BK), bahan organik $(\mathrm{BO})$, total digestible nutrien $(\mathrm{TDN})$, kecernaan $\mathrm{BK}(\mathrm{KcBK})$, kecernaan $\mathrm{BO}(\mathrm{KcBO})$ dan kecernaan serat kasar $(\mathrm{KcSK})$, tetapi berpengaruh $(\mathrm{P}<0,05)$ terhadap kecernaan energi. Kesimpulannya suplementasi Heit-CHrose pada pakan sapi perah mampu meningkatkan kecernaan energi dibandingkan pakan kontrol, serta tidak berdampak negatif terhadap konsumsi pakan dan kecernaan nutriennya.

(Kata kunci: Sapi perah, Heit-CHrose, Konsumsi pakan, Kecernaan nutrien)

\section{ABSTRACT}

This study was aimed to determine the feed intake and digestibility of nutrients in dairy cows with organic minerals (organic Cr $1.5 \mathrm{ppm}$, organic Se $0.3 \mathrm{ppm}$; Zn-Lyzinat $40 \mathrm{ppm}$ ) and Heit-CHrose $0.18 \% \mathrm{Kg} \mathrm{DM}$ supplements. The experiment was conducted using third-lactation dairy cows with the average body weight of $638 \pm 72 \mathrm{~kg}$. There were 16 head of cows that were divided into 4 treatments, which were R0 : control diet, R1:R0 plus organic mineral supplemention, $R 2: R 1$ plus Heit-CHrose supplement, fed in separate ration, $R 3: R 2$ that was fed as a total mixed ration (TMR). The experiment was designed completely random with four replications for each treatment. The data were tested using analysis of variance. The significant difference between treatment was tested using a honestly significant different (HSD) test. The results showed that the supplementation of organic minerals and HeitCHrose dairy cows rations did not give significant effect on dry matter intake (DMI), organic matter intake (OMI), total digestible nutrients intake (TDNI), dry matter digestibility (DMD), organic matter digestibility (OMD) and crude fiber digestibility $(C F D)$, but affectthe digestibility of energy $(P<0.05)$. Heit-CHrose supplementation to dairy cattle ration more increases digestibility of energy compared to the control diet, and have no negative affect the feed intake and digestibility of nutrients.

(Key words: Dairy cow, Heit-CHrose, Feed consumption, Nutrient digestibility)

\section{Pendahuluan}

Evaluasi bahan pakan (suplemen pakan) pada ternak dapat dilakukan melalui konsumsi dan kecernaannya. Konsumsi pakan yang tinggi tidak serta merta diikuti oleh kecernaan yang tinggi pula. Kecernaan pakan menggambarkan berapa nutrien pakan yang bisa dimanfaatkan ternak untuk memenuhi kebutuhan hidup pokok dan produksi. Heit-CHrose merupakan suplemen organik yang

\footnotetext{
* Korespondensi (corresponding author):

Telp. +62 8164282468

E-mail: caribu_prayitno@yahoo.co.id
}

mengandung senyawa saponin, allisin, dan mineral $\mathrm{Cr}$, Se, dan $\mathrm{Zn}$. Saponin merupakan senyawa yang efektif digunakan sebagai agen defaunasi (Wina et al., 2006; Suharti et al., 2009), allisin merupakan senyawa yang bersifat metan inhibitor (Hart et al., 2006; Kongmun et al., 2010), mineral Cr, Se, dan Zn merupakan mineral esensial yang dibutuhkan oleh mikroba rumen (Jayanegara et al., 2006) dan mampu meningkatkan kecernaan bahan kering dan bahan organik pada sapi perah (Prayitno dan Widiyastuti, 2010). Suplementasi Heit-CHrose 
diharapkan mampu memperbaiki efisiensi fermentasi di dalam rumen dengan adanya penurunan populasi protozoa sebagai akibat adanya defaunasi dari saponin dan menurunnya produksi metan dengan adanya metan inhibitor dari allisin. $\mathrm{Di}$ sisi lain, adanya mineral $\mathrm{Se}, \mathrm{Cr}$, dan $\mathrm{Zn}$ diharapkan mampu meningkatkan metabolisme, khususnya metabolisme energi. Pola pemberian pakan, konvensional (top dress ration) dan total mixed ration (TMR) akan mempengaruhi konsumsi dan kecernaan pakan, karena adanya perbedaan pengaruh pakan selama tinggal di saluran pencernaan (rumen). Tujuan dari penelitian ini untuk mengkaji suplementasi Heit-CHrose pada pakan sapi perah terhadap konsumsi dan kecernaan pakan.

\section{Materi dan Metode}

Penelitian dilaksanakan di kandang Balai Besar Perbibitan Ternak Unggul (BBPTU) Sapi perah, Baturaden, Banyumas selama 4 bulan dan dilanjutkan di Laboratorium Ilmu Bahan Makanan Ternak Fakultas Peternakan, Universitas Jenderal Soedirman.

\section{Materi}

Materi yang digunakan dalam penelitian ini adalah sapi perah peranakan FH sebanyak 16 ekor masa kering bunting (dry off), dengan rataan bobot badan $638 \pm 72 \mathrm{~kg}$, periode laktasi ketiga, dan produksi rata-rata 12-14 liter/ekor/hari, konsentrat (pakan perlakuan) sapi perah dengan kandungan PK $13,79 \%$ dan TDN 67\%, Heit-CHrose (mengandung senyawa saponin, allicin, 1,5 ppm Chromium, 0,3 ppm Selenium dan 40 ppm Zinc organik). Peralatan yang digunakan dalam penelitian ini adalah timbangan shelter (merk Jason type 367-090) kapasitas $50 \mathrm{~kg}$ dengan ketelitian 100 gram, kantong pakan, dan bak plastik.

Pakan yang diberikan adalah hijauan (hijauan terdiri atas rumput gajah $57 \%$ dan Glirisidae 3\%) dan konsentrat dengan perbandingan 60:40, dengan komposisi nutrien bahan pakan hijauan dan konsentrat seperti tersaji pada Tabel 1.

Tahap adaptasi. Periode adaptasi dilakukan selama 21 hari pada sapi bunting menjelang partum.

Tahap pengumpulan data. Pengumpulan data dilakukan pada saat sapi awal laktasi sampai hari ke-42 yaitu meliputi tahap pengukuran konsumsi pakan harian dan koleksi feses. Pengukuran konsumsi pakan dilakukan setiap hari sampai penelitian selesai. Koleksi feses dilakukan menggunakan metode koleksi total selama 5 hari pada akhir penelitian dengan tahapan sebagai berikut : 1) Menimbang pakan pemberian dan sisa, serta mengukur BK pakan pemberian dan sisa; 2) Menampung feses pada bak yang sudah disiapkan dan menyemprotkan formalin 5\% setiap 4 jam sekali untuk mencegah kerusakan nutriennya dan kemudian setelah 24 jam menimbang feses serta diukur BK fesesnya; 3) Selama jeda waktu dari pengumpulan sampel pakan pemberian, pakan sisa, dan feses, sampai pengovenan, sampel tersebut dijaga keadaannya agar tidak ada perubahan fisik dan kimia; 4) Melakukan pengambilan sampel pakan pemberian, pakan sisa, dan feses; 5) Mengeringkan sampel pakan pemberian, pakan sisa, dan feses dalam oven pada suhu $60^{\circ} \mathrm{C}$ selama 48 jam; dan 6) Sampel pakan pemberian, pakan sisa, dan feses yang sudah kering digiling dan dianalisis proksimat sesuai petunjuk AOAC (1990), untuk menentukan nilai kecernaannya.

\section{Analisis data}

Data hasil penelitian dianalisis menggunakan analisis variansi dengan Rancangan Acak Lengkap, untuk mengetahui adanya perbedaan antar perlakuan dilakukan uji beda nyata jujur (BNJ) (Steel dan Torrie, 1993).

\section{Hasil dan Pembahasan}

\section{Konsumsi pakan}

Pengaruh perlakuan suplementasi mineral organik dan Heit-CHrose terhadap konsumsi bahan kering, bahan organik dan total digestible nutrien (TDN) tersaji pada Tabel 2.

Suplementasi mineral organik dan HeitCHrose tidak memberikan pengaruh yang nyata $(\mathrm{P}>0,05)$ terhadap konsumsi bahan kering, bahan organik dan TDN). Tidak adanya perbedaan pada konsumsi ini kemungkinan disebabkan karena penambahan mineral organik dan Heit-CHrose tidak mempengaruhi kadar $\mathrm{BK}$, BO, dan TDN dalam pakan serta tingkat palatabilitas pakan. Selain itu secara fisik dan kimia, bentuk pakan dan kandungan pakan tidak mengalami perubahan antar perlakuan, sehingga tidak mempengaruhi palatabilitas dan tidak berpengaruh terhadap konsumsi BK (Sucipto, 2005).

Konsumsi BK pada penelitian lebih dari $2,9 \%$ dari bobot tubuh ternak, hal ini telah sesuai karena kebutuhan BK ternak idealnya adalah 2-4\% (NRC, 2001). Penelitian ini sejalan dengan pendapat Astuti et al. (2008) yang menyatakan bahwa penambahan saponin sebesar $0,069 \%$ pada pakan sapi potong Peranakan Ongole (PO) tidak berpengaruh terhadap konsumsi BK maupun konversi pakan. Lebih lanjut dikemukakan bahwa pemberian saponin $0,069 \%$ cenderung menurunkan konsumsi BK sekitar 4\%.

Kandungan bahan organik merupakan komponen terbesar dalam bahan kering, sehingga konsumsi BO akan mengikuti pola dari konsumsi BK. Konsumsi TDN akan mengikuti pola konsumsi 
Tabel 1. Susunan pakan yang digunakan dalam penelitian (experimental diet composition)

\begin{tabular}{|c|c|c|c|c|}
\hline Komposisi (composition) & R0 & $\mathrm{R} 1$ & $\mathrm{R} 2$ & R3 \\
\hline \multicolumn{5}{|l|}{ Hijauan (60\%) (forage (60\%)) } \\
\hline Pennisetum purpureum (\%) & 95,00 & 95,00 & 95,00 & 95,00 \\
\hline Glirisidae (\%) & 5,00 & 5,00 & 5,00 & 5,00 \\
\hline \multicolumn{5}{|l|}{ Konsentrat (40\%) (concentrate (40\%)) } \\
\hline Dedak padi (\%) (rice bran (\%)) & 19,00 & 19,00 & 19,00 & 19,00 \\
\hline Tepung jagung (\%) (corn mash (\%)) & 5,00 & 5,00 & 5,00 & 5,00 \\
\hline Bungkil kelapa (\%) (coconut meal (\%)) & 29,00 & 29,00 & 29,00 & 29,00 \\
\hline Bungkil kedelai (\%) (soy bean meal (\%)) & 7,00 & 7,00 & 7,00 & 7,00 \\
\hline Pollard (\%) & 20,00 & 20,00 & 20,00 & 20,00 \\
\hline Onggok (\%) & 17,00 & 17,00 & 17,00 & 17,00 \\
\hline Mineral $(\%)$ & 2,00 & 2,00 & 2,00 & 2,00 \\
\hline Garam (\%) (salt (\%)) & 1,00 & 1,00 & 1,00 & 1,00 \\
\hline Cr Organic* & - & 1,50 & 1,50 & 1,50 \\
\hline Se Organic* & - & 0,30 & 0,30 & 0,30 \\
\hline Zn-Lyzinat* & - & 40,00 & 40,00 & 40,00 \\
\hline Heit-CHrose** & - & - & 0,18 & 0,18 \\
\hline Nutrien (nutrient) & \multicolumn{4}{|c|}{$\ldots \ldots \ldots . . \%$ \% …..... } \\
\hline $\mathrm{BK}(\%)(D M(\%))$ & 46,16 & 46,06 & 45,98 & 45,98 \\
\hline PK (\%) $(C P(\%))$ & 13,79 & 13,82 & 13,60 & 13,60 \\
\hline SK $(\%)(C F(\%))$ & 21,27 & 21,23 & 21,17 & 21,17 \\
\hline LK (\%) (fat (\%)) & 4,15 & 4,12 & 4,02 & 4,02 \\
\hline Abu (\%) (ash (\%)) & 12,08 & 11,99 & 12,06 & 12,06 \\
\hline BETN (\%) & 48,71 & 48,84 & 49,14 & 49,14 \\
\hline $\operatorname{TDN}(\%)^{* * *}$ & 67,02 & 67,04 & 66,96 & 66,96 \\
\hline
\end{tabular}

R0: kontrol, R1: R0+Cr organik 1,5 ppm, Se organik 0,3 ppm, dan Zn Lyzinat 40 ppm, R2: R1+ HeitCHrose $0,18 \% / \mathrm{kg}$ DMI dengan sistem pemberian konvensional, R3: R2 dengan sistem pemberian total mixed ration (R0: control, R1: R0+1.5 ppm organic Cr, 0.3 ppm organic Se and 40 ppm lyzinat $Z n$, $R 2: R 1+0.18 \% / \mathrm{kg} D M I$ Heit-CHrose with conventional feeding system, R3: R2 with total mixed ration feeding system).

* : ppm, **: \% $\% \mathrm{~kg} \mathrm{DM}^{-1}, * * *$ : dihitung dengan rumus \% TDN = 70,60+0,259 PK+1,01 LK-0,76 SK+0,0991 BETN (Sutardi, 2001).

BK: bahan kering (dry matter), PK: protein kasar (crude protein), SK: serat kasar (crude fiber), BETN: bahan ekstrak tanpa nitrogen, TDN: total digestible nutrient.

BK, hal ini disebabkan karena jumlah TDN terkonsumsi akan meningkat atau menurun sejalan dengan tinggi rendahnya konsumsi $\mathrm{BK}$.

Tabel 2 juga menunjukkan tidak adanya perbedaan $(\mathrm{P}>0,05)$ terhadap konsumsi $\mathrm{BK}$ pakan pada sistem konvensional (R2) dibanding sistem TMR (R3). Hal ini tidak selaras dengan penelitian O'Neill et al. (2011) yang menyatakan bahwa sistem pemberian pakan secara TMR mampu meningkatkan konsumsi BK dibandingkan dengan pemberian pakan sistem konvensional. Santos et al. (2010) menambahkan bahwa konsumsi pakan sapi perah juga dipengaruhi oleh produksi susu.

\section{Kecernaan nutrien pakan}

Kecernaan nutrien pada sapi perah laktasi yang mendapat suplementasi mineral organik dan Heit-CHrose tersaji pada Tabel 3. Secara statistika, 
membuat $\mathrm{pH}$ rumen menjadi lebih stabil dan cenderung meningkatkan konsumsi BK, sehingga kinerja bakteri rumen pun akan optimal. Dengan demikian kecernaan $\mathrm{BK}$ dan $\mathrm{BO}$ juga akan meningkat. Meningkatnya kecernaan BK dan BO diduga dipengaruhi oleh adanya $\mathrm{Cr}$, Se, dan Zinc organik dalam Heit-CHrose. Prayitno dan Widiyastuti (2010) menyatakan bahwa pemberian $\mathrm{Cr}$, Se, dan Zinc lisinat pada pakan sapi perah mampu meningkatkan kecernaan BK dan BO.

Penelitian metanogenesis yang dilakukan oleh Meyer et al. (2009); Malecky et al. (2009); dan Santos et al. (2010) menunjukkan bahwa pemberian saponin dan senyawa anti metanogenesis tidak memberikan pengaruh terhadap $\mathrm{KcBK}, \mathrm{KcBO}$ maupun KcSK. Penambahan agen defaunasi tidak mempengaruhi kadar BK, BO maupun kadar SK dari pakan perlakuan. Patra (2011) menambahkan bahwa metanogenesis cenderung akan menurunkan kecernaan serat kasar, hal ini dikarenakan bakteri pendegradasi protein, pati, dan serat mengalami penurunan populasi.

Penelitian metanogenesis pada sapi perah yang dilakukan oleh Yang et al. (2007) menggunakan monensin, garlic, dan juniper ternyata secara total tidak berpengaruh terhadap $\mathrm{KcBK}$, $\mathrm{KcBO}$, kecernan NDF maupun ADF, serta kecernaan pati tetapi di dalam rumen penambahan garlic dan juniper menghasilkan perbedaan pada $\mathrm{KcBK}$ dan KcBO. Bila dibandingkan dengan penelitian ini $\mathrm{KcBK}$ dan $\mathrm{KcBO}$ akibat penambahan allicin sebagai metan inhibitor yaitu $68,8 \%$ vs $66,06 \%$ dan $70,6 \%$ vs $58,15 \%$. Secara garis besar tidak ada perbedaan pada KcBK akibat penambahan Heit-CHrose pada penelitian ini, akan tetapi terdapat perbedaan yang cukup jauh pada KBO yakni sekitar 12,45\%. Hasil analisis variansi menunjukkan bahwa suplementasi mineral $\mathrm{Se}, \mathrm{Cr}$, dan $\mathrm{Zn}$ maupun kombinasi 3 mineral di atas dengan Heit-CHrose secara konvensional mampu meningkatkan kecernaan energi. Kecernaan energi tertinggi terdapat pada R2, hal ini karena pada perlakuan ini pakan diberikan secara sistem konvensional, dengan demikian pemberian konsentrat yang lebih dahulu daripada hijauan akan memacu pertumbuhan mikroba rumen sehingga akan menghasilkan energi yang lebih tinggi dan akan lebih cepat diabsorbsi oleh tubuh ternak daripada pemberian pakan secara sistem TMR. Fermentasi konsentrat dalam rumen akan berjalan lebih cepat bila dibandingkan dengan konsentrat yang dicampur hijauan. Hal ini karena konsentrat akan langsung difermentasi oleh mikroba rumen menjadi volatile fatty acid (VFA), dimana VFA nantinya akan digunakan oleh mikroba rumen sebagai sumber energi.

Perlakuan tidak memberikan pengaruh yang signifikan terhadap $\mathrm{KcBK}, \mathrm{KcBO}$, dan $\mathrm{KcSK}$. Wina et al. (2005) menyatakan bahwa bakteri dalam rumen akan memberikan respon yang berbeda-beda dalam mencerna nutrien pakan meskipun telah diberikan agen defunasi berupa ekstrak metanol lerak. Penelitian lain, Astuti et al. (2008) menunjukkan bahwa pemberian pakan aditif pada sapi PO berupa lerak (sumber saponin) dalam ransum bentuk mash, mempunyai kecernaan BK dan SK yang lebih rendah daripada penelitian ini $(56,19 \%$ dan 36,44\%).

Yang et al. (2007) menyatakan bahwa penambahan garlic maupun minyak essensial juniper meskipun tidak menunjukkan perbedaan terhadap kecernaan nutriennya, akan tetapi cenderung meningkatkan kecernaannya walaupun tidak signifikan. Hal ini dikarenakan penambahan garlic maupun minyak essensial juniper mampu memperbaiki sistem fermentatif rumen. Hal ini juga didukung oleh Holtshausen et al. (2009) yang berpendapat bahwa defaunasi tidak mampu meningkatkan kecernaan nutrien. Peneliti lain menyebutkan bahwa defaunasi justru akan menurunkan kecernaan serat termasuk fraksi neutral detergent fiber (NDF) maupun acid detergent fiber (ADF). Hess et al. (2004) dan Santoso et al. (2004) melaporkan bahwa penekanan produksi metan (metanogenesis) menggunakan S. saponaria dan $Y$. schidigera, akan menurunkan total kecernaan serat dan fraksinya. Sedangkan Pen et al. (2007) berpendapat bahwa penambahan $Q$. saponaria mampu meningkatkan kecernaan NDF.

Hasil uji lanjut BNJ menunjukkan bahwa tidak ada perbedaan pada seluruh kecernaan nutrien antara R2 dengan R3. Hal ini disebabkan penambahan mineral organik dan Heit-CHrose tidak memberikan pengaruh terhadap kadar BK, BO, SK, dan energi pada pakan perlakuan. Sistim pemberian pakan secara TMR pada penelitian ini tidak mampu memperbaiki ekologi rumen, tidak menstimulasi aktifitas mikroba rumen dalam mencerna serat.

\section{Kesimpulan}

Suplementasi mineral organik dapat meningkatkan konsumsi per kg bobot badan ternak dan meningkatkan kecernaan energi. Suplementasi HeitCHrose pada pakan sapi perah tidak berdampak negatif terhadap konsumsi pakan dan kecernaan nutriennya. 


\section{Daftar Pustaka}

AOAC. 1990. Official Methode of Analysis. Association of Official Agricultural Chemist. Agricultural Chemicals; Contaminants and Drugs. Vol 2. Association of Official Agricultural Chemist., Inc. Virginia.

Astuti. D. A., E. Wina, B. Haryanto, dan S. Suharti. 2008. Suplementasi lerak berbentuk pakan blok untuk meningkatkan produksi dan kualitas daging sapi potong serta pengaruhnya terhadap keseimbangan mikroba rumen. Laporan akhir penelitian. Lembaga Penelitian dan Pengabdian kepada Masyarakat. IPB bekerja sama dengan Sekretariat Badan Penelitian dan Pengembangan Pertanian, Bogor.

Hart, K. J., S. E. Girdwood, S. Taylor, D. R. YanezRuiz and C. J. Newbold. 2006. Effect of allicin on fermentation and microbial populations in the rumen simulating fermentor Rusitec. Reprod. Nutr. Dev. 46 (Supplement 1): 97-115.

Hess, H. D., R. A. Beuret, M. Lotscher, I. K. Hindrichsen, A. Machmuller, J. E. Carulla, C. E. Lascano and M. Kreuzer. 2004. Ruminal fermentation, methanogenesis and nitrogen utilization of sheep receiving tropical grass hay-concentrate diets offered with Sapindus saponaria fruits and Cratylia argentea foliage. J. Anim. Sci. 79: 177-189.

Holtshausen, L., A. V. Chaves, K. A. Beauchemin, S. M. McGinn, T. A. McAllister, N. E. Odongo, P. R. Cheeke and C. Benchaar. 2009. Feeding saponin-containing Yucca schidigera and Quillaja saponaria to decrease enteric methane production in dairy cows. J. Dairy Sci. 92: 2809-2821.

Jayanegara, A., A. S. Tjakradidjaja and T. Sutardi. 2006. Fermentability and in vitro digestibility of the ration agroindustry waste supplemented with inorganic and organic chromium. Media Peternakan 29: 54-62.

Kongmun, P., M. Wanapat, P. Pakdee and C. Navanukraw. 2010. Effect of coconut oil and garlic powder on in vitro fermentation using gas production technique. Livest. Sci. 127: 38-44.

Malecky, M., L. P. Broudiscou and P. Schmidely. 2009. Effect of two levels of monoterpene blend of rumen fermentation, terpene and nutrien flows in the duodenum and milk production in dairy goats. Anim. Feed Sci. Technol. 154: 24-35.
Meyer, N. F., G. E. Erickson, T. J. Klopfenstein, M. A. Greenquist, M. K. Luebbe, P. Williams and M. A. Engstrom. 2009. Effect of essential oils, tylosin and monensin on finishing steer performance, carcass characteristics, liver abscesses, ruminal fermentation an digestibility. J. Anim. Sci. 87: 2346-2354.

NRC. 2001. Nutrient Requirements of Dairy Cattle. $7^{\text {th }}$ rev. ed. Natl. Acad. Sci., Washington, DC.

O’Neill, B. F., M. H. Deighton, B. M. O'Loughlin, F. J. Mulligan, T. M. Boland, M. O'Donovan and E. Lewis. 2011. Effects of a perennial ryegrass diet or total mixed ration diet offered to spring-calving Holstein-Friesian dairy cows on methane emissions, dry matter intake, and milk production. J. Dairy Sci. 94: 1941-1951.

Patra, A. K. 2011. Effect of essential oil on rumen fermentation, microbial ecology and ruminant production. Asian J. Anim. Vet. Adv. 6: 416428.

Pen, B., K. Takaura, S. Yamaguchi, R. Asa and J. Takahashi. 2007. Effects of Yucca shidigera and Quillaja saponaria with or without $\beta$ 1-4 galacto-oligosaccharides on ruminal fermentation, methane production and nitrogen utilization in sheep. Anim. Feed Sci. Technol. 138: 75-88.

Prayitno, C. H. and T. Widiyastuti. 2010. Studies selenomethionin, yeast chromium, and zinc proteinat on feed dairy cows (Overview of in vitro). Proceedings of the National Seminar : Agribusiness Livestock Development Perspective. Faculty of Animal Science, Jenderal Soedirman University, Purwokerto.

Santos, M. B., P. H. Robinson, P. Williams and R. Losa. 2010. Effects of addition of an essential oil complex to the diet of lactating dairy cows on whole tract digestion of nutrients and productive performance. Anim. Feed Sci. Technol. 157: 64-71.

Santoso, B., B. Mwenya, C. Sar, Y. Gamo, T. Kobayashi, R. Morikawa, K. Kimura, H. Mizukoshi and J. Takahashi. 2004. Effects of supplementing galacto-oligosaccharides, Yucca schidigera or nisin on rumen methanogenesis, nitrogen and energy metabolism in sheep. Livest. Prod. Sci. 91: 209-217.

Steel, R. G. D. dan J. H. Torrie. 1993. Prinsip dan Prosedur Statistika. Suatu Pendekatan Biometrik. Edisi kedua. P.T. Gramedia Pustaka Umum, Jakarta. 
Sucipto. 2005. Tampilan konsumsi pakan, total VFA, $\mathrm{NH}_{3}$ rumen dan kandungan protein susu sapi fresian holstein akibat pemberian tepung daun katu (Souropus androgynus Merr). Tesis. Universitas Diponegoro Semarang.

Suharti, S., D. A. Astuti, dan E. Wina. 2009. Peningkatan efisiensi metabolisme rumen dan produktivitas sapi potong serta penekanan emisi gas metan dengan saponin ekstrak lerak (Sapindus rarak). Lembaga Penelitian dan Pengabdian kepada Masyarakat. Institut Pertanian Bogor, Bogor.

Sutardi, T. 2001. Revitalisasi peternakan sapi perah melalui penggunaan ransum berbasis limbah perkebunan dan suplementasi mineral organik. Laporan Akhir RUT. Kantor Menteri Negara Riset dan Teknologi dan Lembaga Ilmu Pengetahuan Indonesia.

Wina, E., S. Muetzel, E. M. Hoffman, H. P. S. Makkar and K. Becker. 2005. Saponin containing methanol extract of Sapindus rarak affect microbial fermentation, microbial activity and microbial community structure in vitro. J. Anim. Feed Sci. Technol. 121: $159-174$.
Wina, E., S. Muezel and K. Becker. 2006. Effects of daily and interval feeding of Sapindus rarak on protozoa, rumen fermentation parameter and digestibility in sheep. J. Anim. Feed Sci. Technol. 11: 1580-1587.

Wongnen, C., C. Wachirapakorn, C. Patipan, D. Panpong, K. Kongweha, N. Namsaen, P. Gunun and C. Yuangklang. 2009. Effects of fermented total mixed ration and cracked cottonseed on milk yield and milk composition in dairy cows. Asian-Aust. J. Anim. Sci. 22: 1625-1632.

Yang, W. Z., C. Benchaar, B. N. Ametaj, A. V. Chaves, M. L. He and T. A. McAllister. 2007. Effects of garlic and juniper berry essential oils on ruminal fermentation and on the site and extent of digestion in lactating cows. J. Dairy Sci. 90: 5671-5681. 